Türkiye Tarımsal Araştırmalar Dergisi
http://dergi.siirt.edu.tr/index.php/ziraat $\begin{aligned} & \text { Turk J Agric Res } \\ & \text { (2014) 1: 128-137 } \\ & \text { TÜTAD } \\ & \text { ISSN: 2148-2306 }\end{aligned}$

\title{
Siirt İli Bazı Arazi ve Toprak Özelliklerinin Coğrafi Bilgi Sistem Analizleriyle Değerlendirilmesi
}

\author{
Mehmet Arif ÖZYAZICI ${ }^{1 *}$, Orhan DENGIZZ ${ }^{2}$, Ali İMAMOĞLU ${ }^{2}$ \\ ${ }^{1}$ Siirt Üniversitesi, Ziraat Fakültesi, Tarla Bitkileri Bölümü, Siirt, TÜRKiYE \\ ${ }^{2}$ Ondokuz Mayls Üniversitesi, Ziraat Fakültesi, Toprak Bilimi ve Bitki Besleme Bölümü, Samsun, TÜRKIYE
}

\begin{tabular}{ll}
\hline Geliş Tarihi/Received: 19.04 .2014 & Kabul Tarihi/Accepted: 09.08 .2014 \\
\hline "Sorumlu Yazar/Correspondence: arifozyazici@siirt.edu.tr &
\end{tabular}

Özet: Bu çalışmanın amacı Siirt ili bazı arazi ve toprak özelliklerinin Coğrafi Bilgi Sistemi (CBS) kullanılarak belirlenmesi ve veritabanının oluşturulmasıdır. Çalışma alanı 562619.5 hektardır. Araştırmada öncelikle Siirt iline ait topoğrafya haritası kullanılarak arazinin sayısal yükselti modeli oluşturulmuş ve eğim, bakı, yükselti ve kabartı haritaları üretilmiştir. Ayrıca çalışmada, Köy Hizmetleri Genel Müdürlüğü tarafından hazırlanan verilerin yanı sıra, İl'e ait iklim verilerinden de yararlanılmıştır. Araştırma sonucunda elde edilen bilgilere göre, Siirt ilinin batı kesimi daha düz ve düze yakın ovalık arazilerden oluşurken, kuzeyi ve doğusunda rakım yüksektir. Bu yüzden eğim değerleri kuzey ve doğu bölgelerinde yüksek, batıda ise düşüktür. Siirt ilinin yarısından çoğunda yaklaşık \% 65 'inde kahverengi orman toprăg bulunur. Arazi kullanım haritasına baktığımızda ilin \% 44'lük kısmının fundalık, \% 31'lik kısmının ise meralık arazilerden oluștuğu görülmektedir. Erozyon haritasının incelenmesi sonucu ise Siirt ilinin yaklaşık \% 90'ında orta, şiddetli ve çok şiddetli erozyon olduğu görülmüştür. İşlemeli tarıma uygun araziler ilde oldukça sınırlıdır. Siirt ili toplam alanının sadece \% 9’luk kısmı I., II. ve III. sınıf kabiliyete sahip alanlardan oluşmaktadır. Toprak derinlik haritası incelendiğinde ise \% 85 oranıyla sahanın büyük kısmının çok sığ ve sığ topraklardan oluştuğu görülmektedir. Derin ve çok derin toprakların ise batıda ovalık arazilerde ve vadilerde küçük alanlarda yer alır.

Anahtar Kelimeler: Arazi-toprak kaynakları, coğrafi bilgi sistemi, Siirt

\section{Determination of Some Land and Soil Characteristics of Siirt Province with Geographic Information System Analysis}

\begin{abstract}
The main aim of this research was to determine some land and soil characteristics of Siirt province and to make database using Geographic Information System (GIS). The study area covers about 562619.5 ha. Firstly, digital elevation model was formed using topographic map of the Siirt province and after this process slope, aspect, elevation and hill shade maps were also produced. In addition to that, some data produced General Directory of Rural Services and climate data were used in this study. According to study results, west part of the Siirt province has almost flat area whereas, hilly and mountain area locate in north and east part of it. Therefore, slope degree increase from west to north and east ways. More than half of the study area's soil types (65\%) is Brown forest soils. Besides, according to land use and land cover map about $44 \%$ and $31 \%$ of the study area covers by shrubbery-brush and pastures, respectively. According to erosion maps, approximately $\% 90$ of the Siirt province lands has medium, severe and very severe erosion problem. Lands that are suitable for agricultural activities are very limited in Siirt Province. Only about $9 \%$ of the total land was classified as I, II and III land capability classes. Moreover, investigated depth map of the study area about $85 \%$ of the study area has very shallow and shallow soil depth. Deep soils found on plain and valley located at west part of the study area.
\end{abstract}

Keywords: Land-soil resource, geographic information system, Siirt 


\section{Giriș}

Ülkemizin toprak potansiyeli bilinçsizce kullanılmaktadır. Mevcut topraklarımızın özelliklerinin ve arazi kaynaklarımızın belirlenmesi ve etkili kullanımı, ülkemizin geleceği açısından bir zorunluluktur. Arazilere ait temel özelliklerini içeren sağlıklı bir envanterin elde olması, bu kaynaklar üzerinde yapılacak her türlü planlamanın sağlıklı temeller üzerine oturmasına imkân sağlayacaktır (Akgül ve Başayiğit, 2005). Bu amaçla toprak etütleri ve bunun sonucunda hazırlanan toprak haritaları büyük önem taşımaktadır. Zira yöresel, bölgesel ve ulusal planlamalara geçmeden önce arazi kaynaklarının niteliksel ve niceliksel olarak incelenmesi, eldeki kaynakların potansiyellerinin saptanması, gelişen teknolojilere paralel olarak veri tabanlarının ve haritaların oluşturulmaları gerekmektedir (Dengiz ve Sarığlu, 2011a ve 2011b). Topraksu Genel Müdürlüğü, 1966-1971 yılları arasında 1/25000 ölçekli topoğrafik haritalar kullanarak, Türkiye topraklarını istikşafi düzeyde inceleyerek haritalamıştır. Bu çalışmada, sınıflama için 1938 Amerikan sistemi kullanılmış ve sonuçlar 1/100000 ölçekli il raporları (İl Arazi Varlığı Raporları) şeklinde yayınlanmıştır (Canpolat, 1981). 1/100000 ölçekli eski sınıflama sistemine göre hazırlanmış toprak haritaları bugün için Siirt ilinin (Anonim, 1997) tek veri kaynağıdır. $\mathrm{Bu}$ haritalardan sadece toprak derinliği, eğim, erozyon derecesi, drenaj, tuzluluk, alkalilik, taşlılık, kayalılık, arazi kullanım kabiliyet sınıfi, alt sınıfı ve arazi kullanım durumu bilgileri sağlanabilmektedir. $\mathrm{Bu}$ haritalar sağladıkları bilgiler ile ve ölçekleri nedeniyle detaylı çalışmalar için kullanılamamaktadır. Günümüz teknikleri kullanılarak detaylı toprak etütleri ile toprakların Toprak Taksonomisi'ne göre sinıflandırılıp haritalanmamış olması, ülke genelinde olduğu gibi bugün için Siirt ili topraklarının da en önemli sorunlardan birisi olarak karşımıza çıkmaktadır.

Teknolojinin gelişmesi ile birlikte bilimsel anlamda yapılan çalışmalar hız kazanmıştır. Coğrafi bilgi sistemlerinin hayatımıza girmesiyle toprak gibi çevremiz ile ilgili birçok konuda daha akılcı ve sürdürülebilir planlar yapılmaya başlanmış, Toprak Bilgi Sistemleri gibi uygulamalar hayata geçirilmiştir. Toprak Bilgi Sistemleri, toprak özelliklerinin haritalar halinde sayısal ortamda depolanıp analizlerini temel almaktadir (Harmon ve Anderson, 2003).

$\mathrm{Bu}$ çalışma, Toprak Bilgi Sistemlerine örnek olarak yapılmış olup, Köy Hizmetleri Genel Müdürlüğü tarafindan Türkiye'nin illeri için hazırlanan 1/25000 ölçekli toprak haritalarında yer alan bazı parametreler ile Siirt iline ait sayısal topoğrafik haritadan üretilen bazı parametrelerin (sayısal yükselti modeli, bakı, eğim, yükseklik) analizlerini kapsamaktadır.

\section{Materyal ve Yöntem}

\subsection{Materyal}

Güneydoğu Anadolu Bölgesi'nde yer alan Siirt ili kuzeyden Batman ve Bitlis, batıdan Batman, güneyden Mardin ve Şırnak, doğudan Şırnak ve Van illeri ile çevrilidir (Şekil 1). Siirt ili $41^{\circ} 57^{\prime}$ doğu boylamı ve $37^{\circ} 55^{\prime}$ kuzey enlemi üzerinde bulunur.

Siirt ili topoğrafik olarak ele alındığgnda tamamen dağ ve tepelerden oluştuğu görülür. Ancak Kurtalan ilçesinin bir kısmı ova ağırlıklıdır. Doğuya doğru gidildikçe yükselen dağlardan Pervari ilçesinin Yazlıca (Herekol) Dağı 2943 m, Körkandil Dağ 2821 m, Şirvan Bekravi Dağ 2650 m, Hastelli Dağı 2700 m, Çıraf Dağı 2268 m'lik belli başıı yükseltilerindendir. Botan Çayı takip ettiği güzergâhta 150-200 m'lik vadiler oluşturmuştur. Kurtalan ilçe merkezinden Batman il sınırına kadar uzanan birbirinden kopmuş düzlükler vardır. Fazla geniş olmayan bir sahaya yayılan engebeli bir yapı gösteren ovanın ortalama kot değeri 550-850 m arasındadır (Anonim, 1997).

Siirt, dört mevsimin en belirgin özellikleriyle yaşandığ 1 bir yerdir. Genel olarak karasal iklim hüküm sürmektedir. Yazları sıcak ve kuraktır. Haziran ve Ekim ayları arasında pek yağış görülmez. Güneydoğu Anadolu Projesi'nin faaliyete girmesinden sonra iklim özellikleri bakımından değişiklikler başlamıştır. $\mathrm{Bu}$ dönemden sonra ilkbaharda daha fazla yağış görülmüş, genelde \% 40'ın altında bulunan nem miktarı da bu oranın üstüne çıkmıştır. İlin doğu ve kuzey bölgelerinde kışlar daha sert ve yağışl1, güney ve güneybatı bölgelerinde ise 1 lık geçer. Gece ile gündüz arasındaki sıcaklık farkı fazladır. Rüzgârlar geceleri doğu ve kuzeydoğudan, gündüzleri güney ve güneybatıdan, kışın ise genellikle kuzey ve kuzeybatidan eser (Anonim, 2005). Uzun y1llar (52 yıllık) verilerine göre y1llık; sicaklık ortalamas $16.1{ }^{\circ} \mathrm{C}$, en yüksek sicaklık ortalaması $21.8{ }^{\circ} \mathrm{C}$, en düşük sıcaklık ortalaması $11.1^{\circ} \mathrm{C}$, toplam yağış miktarı ortalamas $1692.0 \mathrm{~mm}$ olarak gerçekleşen ilin, tespit edilen en yüksek hava sıcaklığ $46.0{ }^{\circ} \mathrm{C}$, en düşük hava sicaklığ 1 ise $-15.6{ }^{\circ} \mathrm{C}^{\prime} \operatorname{dir}$ (Anonim, 2014).

Siirt ili kuzey ve doğu kesimleri yükseltinin fazla olduğu yerlerdir. Bu nedenle buralarda yağış miktarı ilin batısındaki daha düz alanlara göre yüksektir. Çevresine göre fazla yağış alan bu dağlık bölge Dicle Irmağı'nın önemli su toplama 
alanlarından birini oluşturmaktadır. Ayrıca il topraklarının tümü Dicle Havzası'na girmektedir.

Siirt ilinin temel bazı coğrafi özelliklerinin belirlenmesi amacıyla materyal olarak kullanılan, il sınırları dâhilinde yer alan 1:25.000 ölçekli sayısal yükseklik paftaları, Harita Genel Komutanlı̆̆ı'ndan temin edilmiştir. İl'e ait bu sayısal topoğrafik paftalardan temel bazı coğrafi haritaların elde edilmesinde de CBS programları olan TNT Mips $6.4 \mathrm{v}$ ve ArcGIS 9.3v kullanılmıştır.

\subsection{Yöntem}

İl sınırları dâhilinde yer alan 1:25.000 ölçekli sayısal yükseklik paftaları CBS ortamında oluşturulan sayısal yükselti modeli yardımıyla alanın üç boyutlu halini gösteren kabartı haritası, eğim, bak1, yükselti gibi haritalar üretilmiştir (Şekil 2). Bu görüntüden vadiler, tepeler ve ovalar belirgin olarak gözlenmektedir.

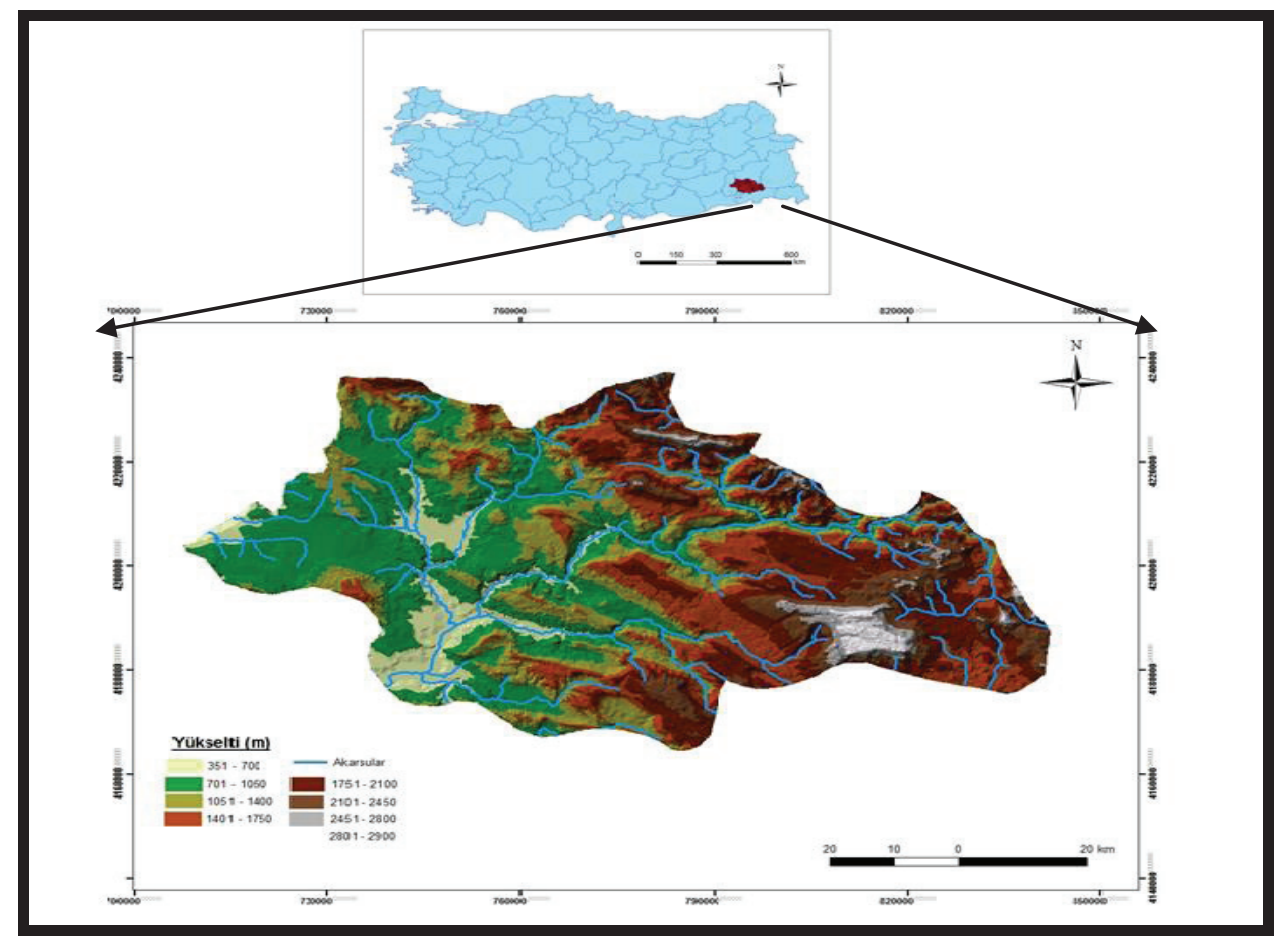

Şekil 1. Siirt ili yer buldur haritası

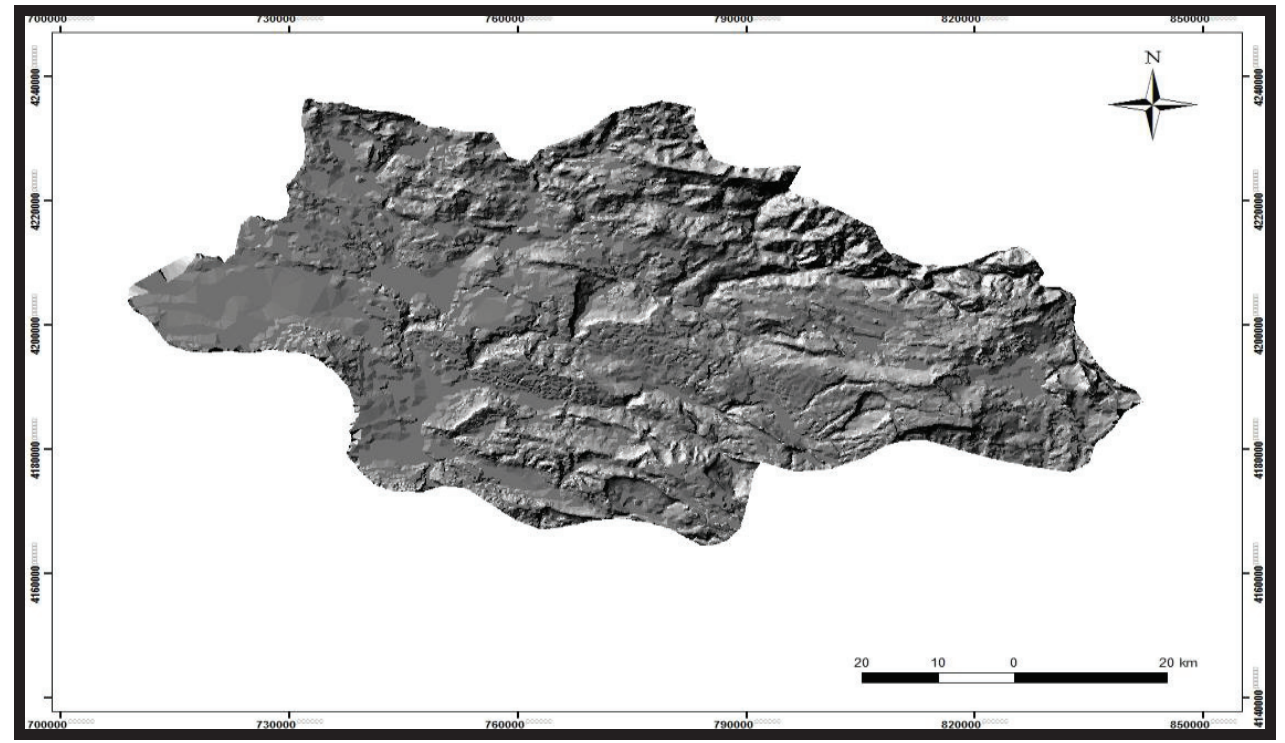

Şekil 2. Siirt ili kabartı haritası 
Ayrıca Köy Hizmetleri Genel Müdürlüğü’nün hazırlanan Siirt il arazi varlığına ait paftalar sayısallaştırarak CBS ortamına aktarılmış ve haritalarda yer alan tüm özellikle öz nitelik tablosu olarak CBS ortamında veri tabanı oluşturulmuştur. Oluşturulan öz nitelik tablosundan yararlanılarak alana ait bazı tematik haritalar örneğin erozyon, toprak derinliği, arazi kullanım kabiliyet sınıfları, arazi kullanım haritaları oluşturulmuştur. Oluşturulan haritalara ait her bir sınıfların yine CBS ortamında alansal ve oransal dağılımları hesaplanmıştır. Son olarak kabartı haritası ile üretilen tematik haritalar bindirme analizi yapılmıştır.

\section{Bulgular ve Tartışma}

\subsection{Siirt ili temel arazi özellikleri}

Eğim, gerek arazi örtü ve arazi kullanım çeşitliliği üzerinde, gerekse de toprak oluşumutoprak çeşitliliği ve toprak erozyon oluşumunda önemli bir faktördür (Dengiz ve ark., 2013). Siirt ili eğim haritası incelendiğinde toplam alanın \% 34.96's1 \% 6'dan düşük eğim değerlerine sahip olduğu görülmektedir. İlin \% 59.53’ü \% 6-30 arasında eğim değerlerine sahiptir. \% 30’un üzerinde eğimli sahalar sadece ilin \% 5.51'inde görülmektedir (Tablo 1). Eğim değerlerinin yüksek olduğu sahalar ilin kuzey ve doğusunda bulunan yüksek sahalarda görülmektedir. İlin batı kısmı ise yükseltisi düşük ova arazilerinden oluşur ve eğim değerleri düşük sahalar buralarda bulunmaktadır (Şekil 3).

Tablo 1. Siirt ili eğim sınıfları

\begin{tabular}{lrr}
\hline Eğim & Alan (ha) & Oran (\%) \\
\hline $0-2$ & 91993.54 & 16.35 \\
$2-6$ & 104705.89 & 18.61 \\
$6-12$ & 127353.58 & 22.64 \\
$12-20$ & 127091.62 & 22.59 \\
$20-30$ & 80500.73 & 14.31 \\
$30+$ & 30974.10 & 5.51 \\
\hline Toplam & 562619.46 & 100.00 \\
\hline
\end{tabular}

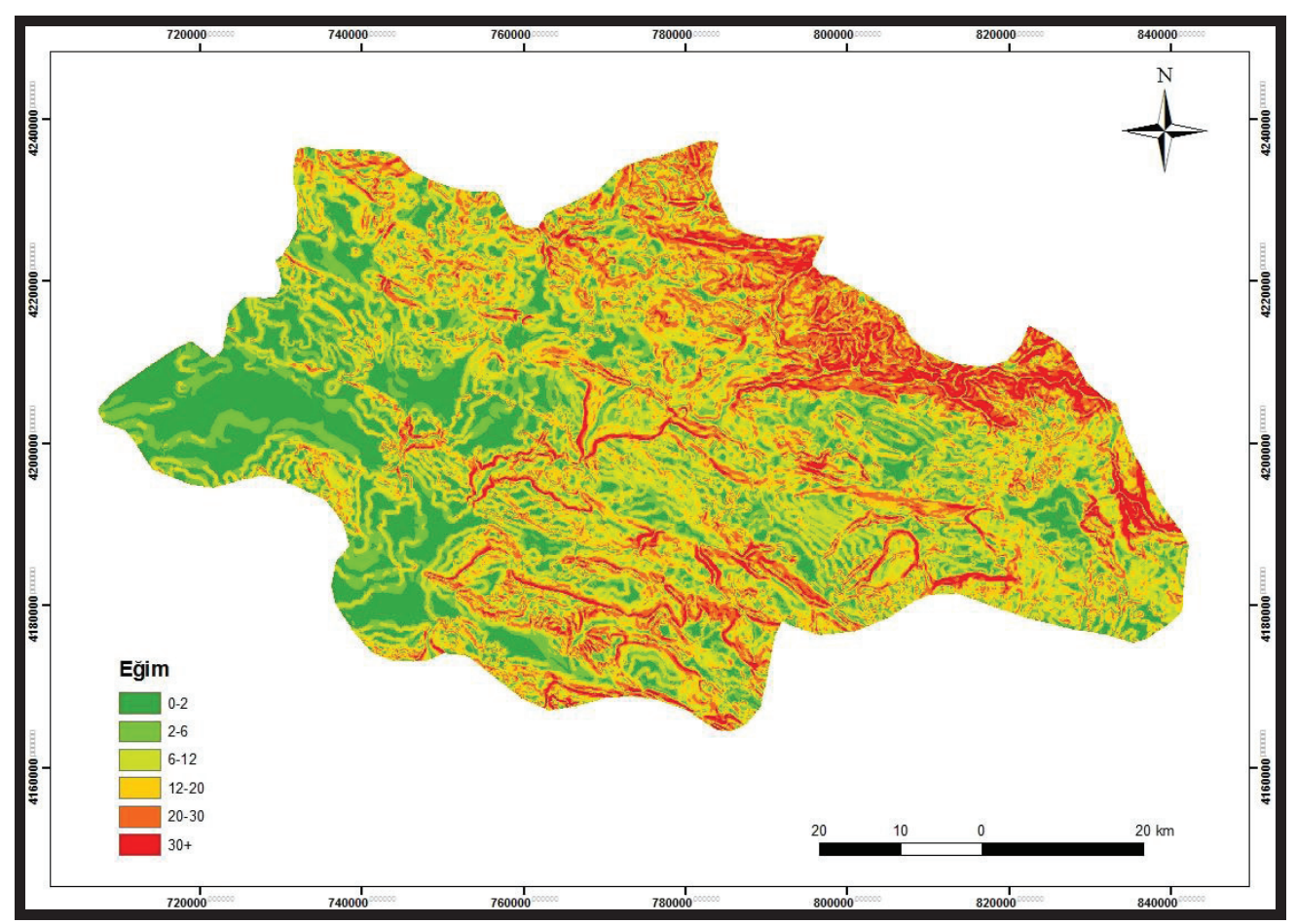

Şekil 3. Siirt ili eğim haritası

Sayısal arazi modelinde bakı, her raster hücresi için hesaplanır. Bakı, ilgili hücreden teğet olarak geçen yüzey normalinin, kuzey doğrultusu ile yaptığı açı olarak hesaplanır. Bu açı 0 (sıfır)'dan başlanarak saat akrebi yönünde 360 derecelik tam bir daire oluşacak şekilde hesaplanır ve sınıflandırılır. Bu aralıklarda olan ve her hücre için hesaplanan bakı değeri, o hücrenin eğim yüzeyinin hangi yöne baktığını gösterir. Araştırma sahası bakı haritasına baktığımızda, Siirt ilinin batı kesimindeki arazilerde düzlük alanların bulunduğu görülmektedir. Fakat doğuda bakının birbirine yakın oranlarda benzer dağılım gösterdiği görülmektedir (Şekil 4). Bunun sebebi sahanın akarsular tarafından bolca yarılmış olmasıdır. 
Ana materyal, iklim, topoğrafya gibi farklılıklara bağlı olarak Siirt ilinde farklı büyük toprak grupları oluşmuştur. Siirt ilinde \% 64.63 oranıyla en yaygın olarak görülen toprak tipi kahverengi orman topraklarıdır. Bu topraklar il genelinde toplamda 363649.03 ha alan kaplamaktadır. \% 14.43 oranıyla kahverengi topraklar da ikinci büyük toprak grubunu oluşturur. Üçüncü büyük toprak grubu ise \% 11.00 oranıyla kireçsiz kahverengi orman topraklarıdır (Şekil 5).

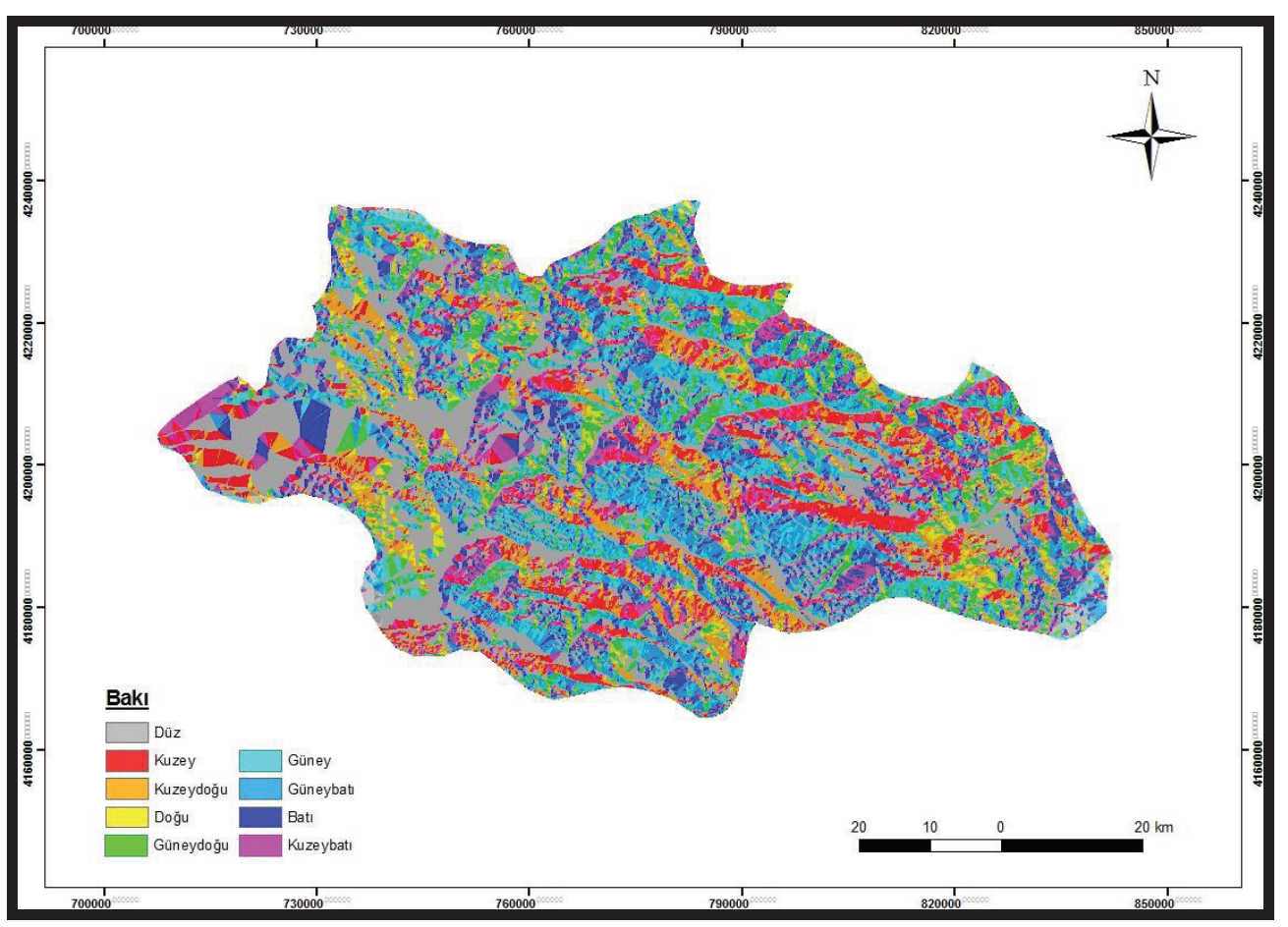

Şekil 4. Siirt ili bakı haritası

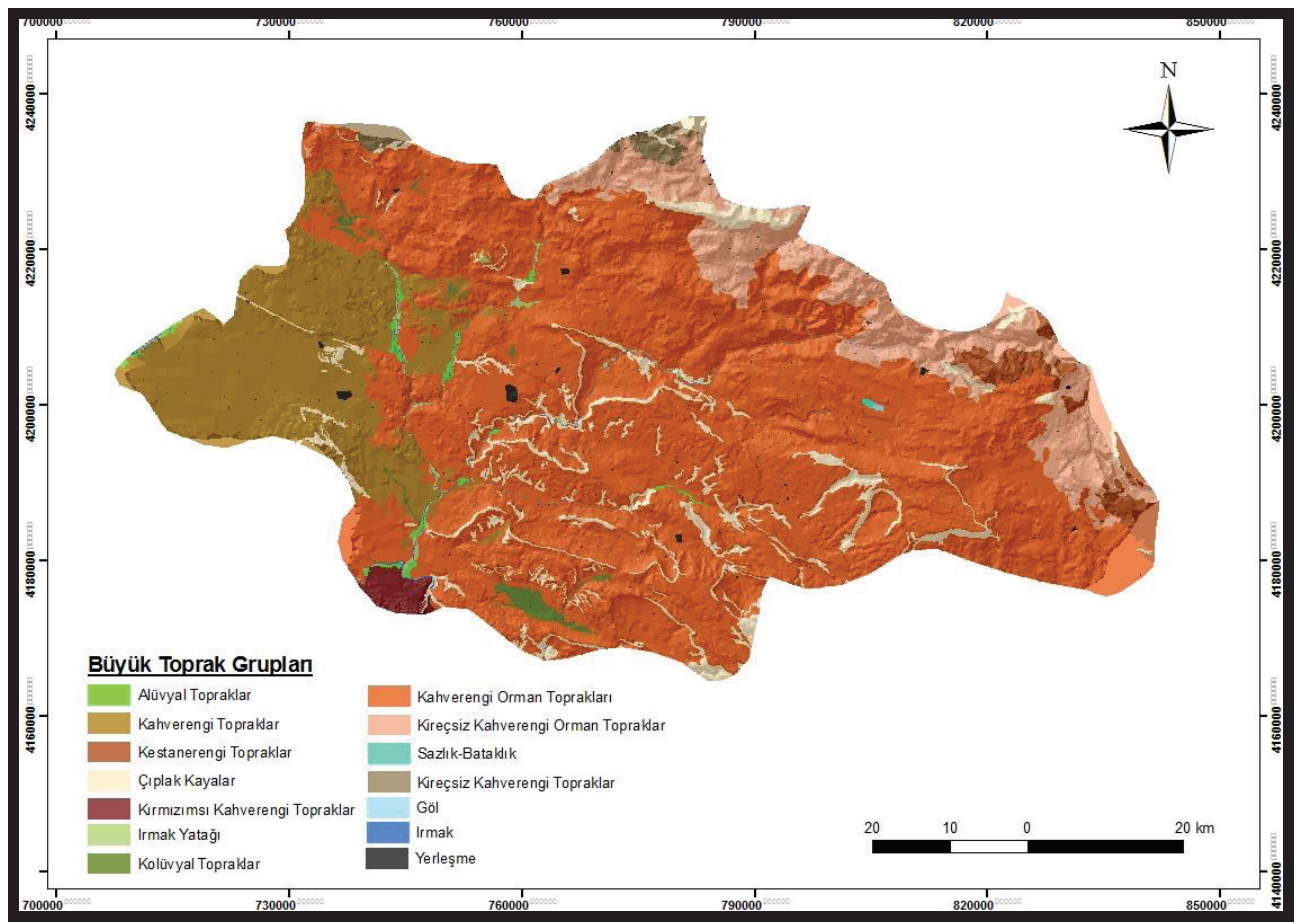

Şekil 5. Siirt ili büyük toprak grupları haritası 
$\mathrm{Bu}$ topraklar kuzey ve doğudaki yüksek kesimlerde görülmektedir. Bol yağışa bağlı olarak yıkanmış topraklardır. Ayrıca verimli arazileri oluşturan alüvyal topraklar 2086.22 ha alanda dağılış göstermektedir. $\mathrm{Bu}$ alanlar çoğunlukla Dicle vadisi içerisindeki sahalardır. Yine Dicle nehri vadisi ve küçük akarsu vadilerinde 3849.64 ha alanda kolüvyal topraklar da yer almaktadır (Tablo 2).

Tablo 2. Siirt ili büyük toprak grupları sınıfları

\begin{tabular}{lrr}
\hline Büyük Toprak Grupları & \multicolumn{1}{c}{$\begin{array}{c}\text { Alan } \\
(\mathrm{ha})\end{array}$} & $\begin{array}{r}\text { Oran } \\
(\%)\end{array}$ \\
\hline A : Aluviyal toprak & 2086.22 & 0.37 \\
B : Kahverengi toprak & 81191.96 & 14.43 \\
CE : Kestane renkli toprak & 9452.16 & 1.68 \\
F : Kırmızımsı kahverengi toprak & 3933.31 & 0.70 \\
K : Koluviyal toprak & 3849.64 & 0.68 \\
M : Kahverengi orman toprağ1 & 363649.03 & 64.63 \\
N : Kireçsiz kahverengi orman & 61903.95 & 11.00 \\
$\quad$ topraklar & & \\
IR : Irmak & 1444.81 & 0.26 \\
GL: Göl & 101.57 & 0.02 \\
SB : Sazlık Bataklık & 120.27 & 0.02 \\
CK: Çılak Kayalık & 33289.07 & 5.92 \\
YR: Yerleşim & 1597.51 & 0.28 \\
\hline Toplam & 562619.50 & 100.00 \\
\hline
\end{tabular}

Arazi kullanımı haritasına bakıldığında ilin $\%$ 43.93'lük oranla 247141.84 ha alanının fundalık olduğu görülmektedir. \% 30.55 oranda ise meralık araziler bulunmaktadır. $\mathrm{Bu}$ arazilerin toplam alanı 171875.81 ha'dır. İlin kuzey ve doğu kesimlerinde 61795.76 ha orman alanı bulunmaktadır. Parçalı şekilde bulunan orman arazileri Siirt'in toplam alanının \% 10.98'ini kaplamaktadır. Çıplak kayalık alanlar ise ilin \% 5.05 'ini kaplamaktadır. Siirt ilinin batı kesiminde bulunan ovalık alanda ise, küçük oranlarda sulu tarım, nadaslı ve nadassız kuru tarım yapılmaktadır (Tablo 3, Şekil 6).

Tablo 3. Siirt ili arazi kullanımı sınıfları

\begin{tabular}{llrr}
\hline \multicolumn{2}{l}{ Arazi Kullanımı } & Alan (ha) & Oran (\%) \\
\hline M & : Mera & 171875.81 & 30.55 \\
S & : Sulu tarım & 4139.84 & 0.74 \\
V & : Bağ (Kuru) & 3497.00 & 0.62 \\
CK & : Çıplak Kayalık & 28384.17 & 5.05 \\
O $\quad$ : Orman & 61795.76 & 10.98 \\
F & : Fundalık & 247141.84 & 43.93 \\
YR & : Yerleşim & 1513.96 & 0.27 \\
K & : Kuru Tarım & 37082.69 & 6.59 \\
Sy & : Sulu Tarım Yetersiz & 2888.94 & 0.51 \\
IY & : Irmak Yatağ1 & 2015.26 & 0.36 \\
C & : Çayır & 601.61 & 0.11 \\
IR & : Irmak & 1322.33 & 0.24 \\
B & : Bahçe (Kuru) & 138.65 & 0.02 \\
GL & : Göl & 101.49 & 0.02 \\
SB & : Sazlık Bataklık & 120.18 & 0.02 \\
\hline Toplam & 562619.53 & 100.00 \\
\hline
\end{tabular}

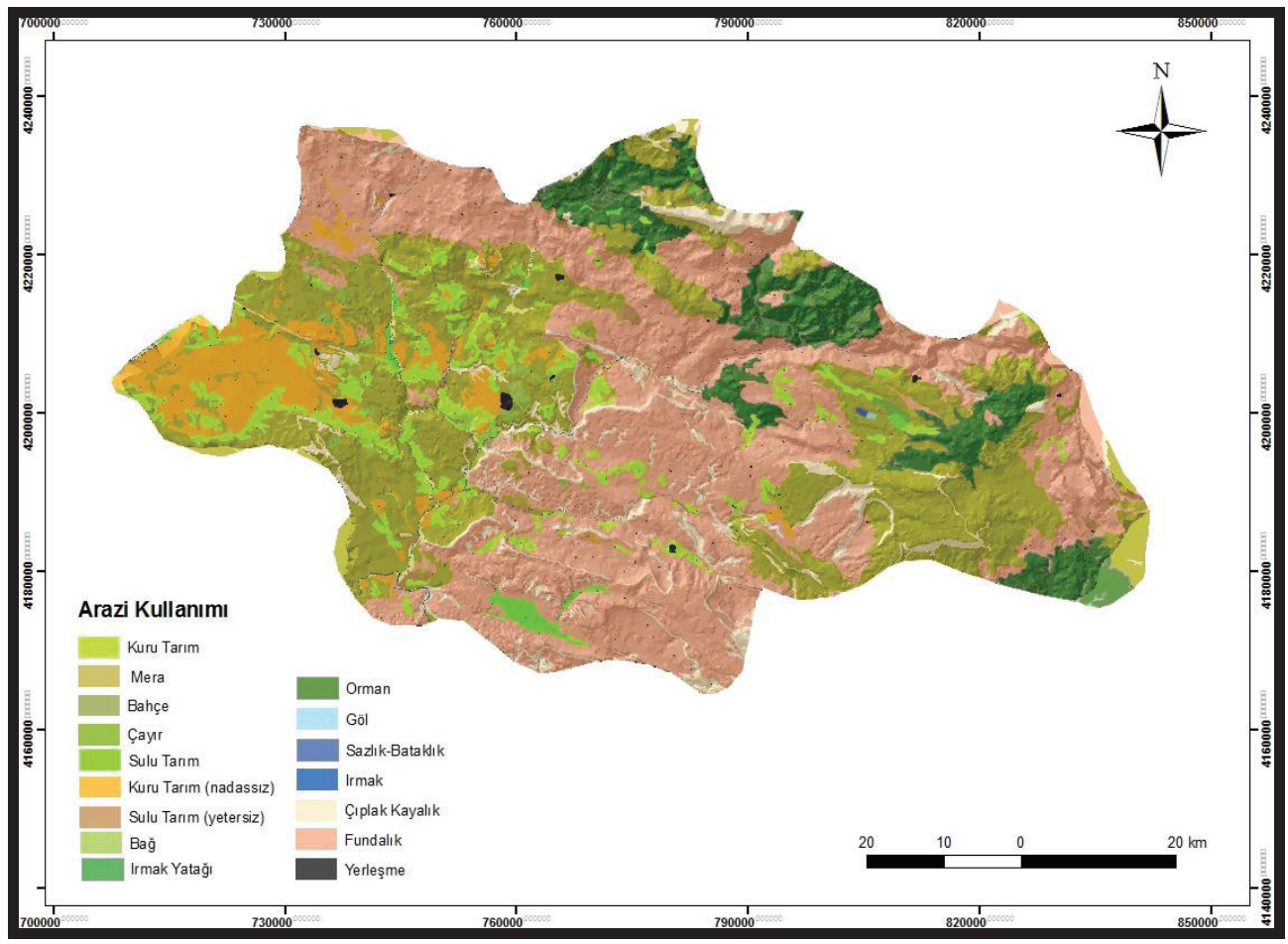

Şekil 6. Siirt ili arazi kullanımı haritası 
Siirt iline ait erozyon haritası incelendiğinde, ilin \% 57.04 oranla yarısından fazla arazisinde çok şiddetli erozyon olduğu görülmektedir. $\%$ 24.00'1nda ise şiddetli erozyon gerçekleşmektedir. Şiddetli ve çok şiddetli erozyon sahalarının toplam alanı 455947.74 ha'dır. Orta şiddetli erozyon alanları ise ilin \% 8.90'1nı kaplamaktadır. Araştırma sahasının batı kısmındaki ovalık arazilerde ise hiç veya çok az erozyon sinıfina giren \% 3.23 oranında arazi bulunmaktadır (Şekil 7, Tablo 4).

Tablo 4. Siirt ili erozyon sinıfları

\begin{tabular}{llr}
\hline Erozyon sinıfları & Alan (ha) & Oran (\%) \\
\hline E1 : Çok az veya yok & 18149.55 & 3.23 \\
E2 : Orta şiddetli & 50057.58 & 8.90 \\
E3 : Şiddetli & 135006.41 & 24.00 \\
E4 : Çok Şiddetli & 320941.33 & 57.04 \\
CK : Çıplak Kayalık & 33393.20 & 5.94 \\
YR : Yerleşim yerleri & 1514.71 & 0.27 \\
IY : Irmak Yatağ & 2015.03 & 0.36 \\
IR : Irmak & 1320.03 & 0.23 \\
GL : Göl & 101.49 & 0.02 \\
SB : Sazlık Bataklık & 120.18 & 0.02 \\
\hline Toplam & 562619.51 & 100.00 \\
\hline
\end{tabular}

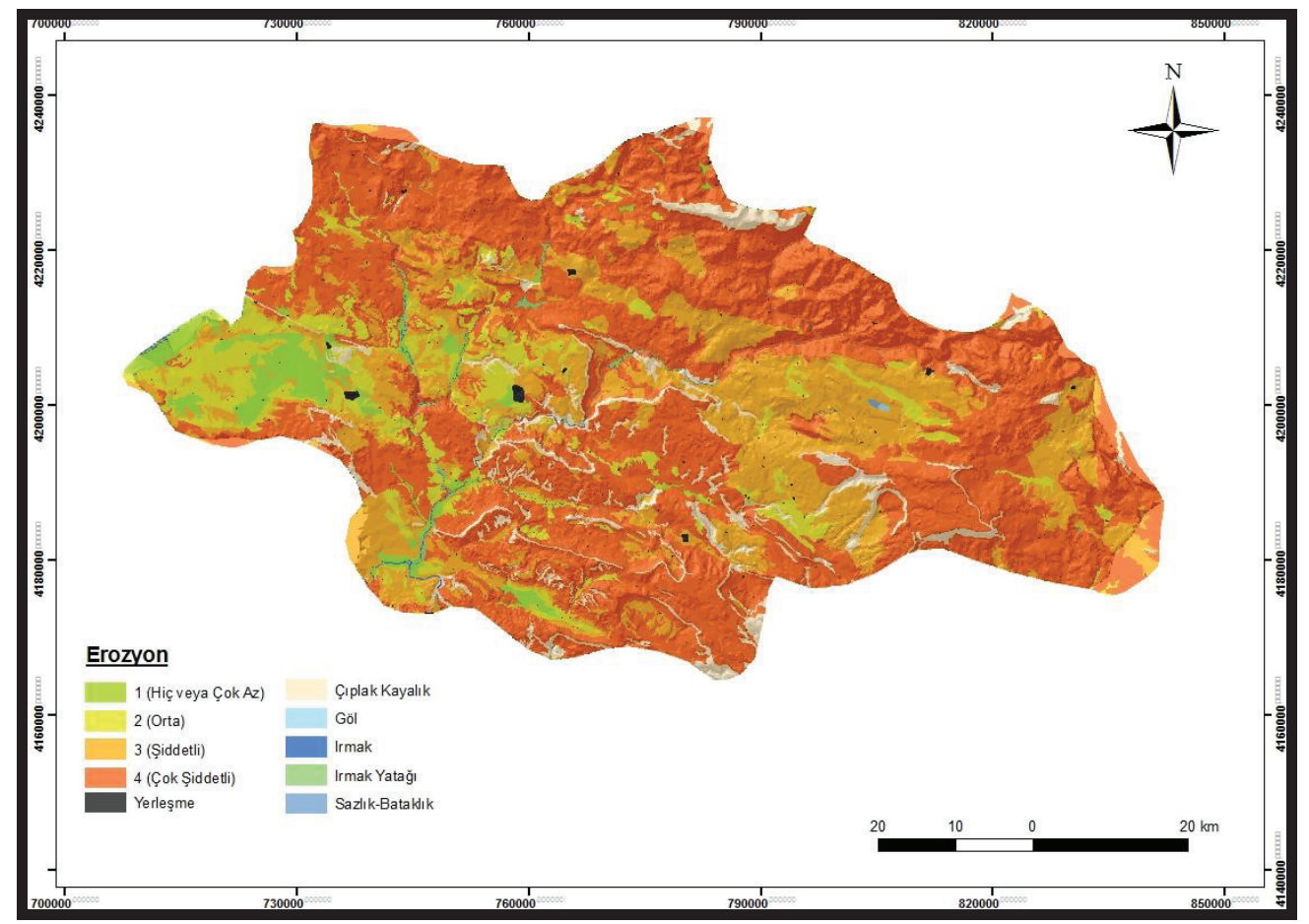

Şekil 7. Siirt ili erozyon haritası

Araştırma sahası arazi kullanım kabiliyet sınıfları haritasına bakıldığında \%67.65 oranla VII. Sınıf arazilerin büyük alan kapladığını görmekteyiz. Bu arazilerin toplam alanı 380586.52 ha'dır. VI. Sinif araziler ise ilin \% 11.41'inde görülmektedir. Ayrıca arazi kullanımı haritasında görülen çıplak kayalık alanlardan oluşan VIII. Sınıf araziler de \% 6.32'lik oranıyla 35530.58 ha alan kaplamaktadır. İşlemeli tarımda kullanılabilme potansiyeli olan \% $0-12$ eğim grubunda yer alan araziler il arazi varlığının çok az bir kısmını oluşturmuştur. Sürdürülebilir tarım için oldukça sınırlı oranda olan bu alanların toprak bozulma süreçlerine karşı korunması gerekmektedir. Verimli arazilerden oluşan I., II.,
III., sinif araziler ise toplamda \% 8.72'lik alanda görülür (Şekil 8, Tablo 5).

Tablo 5. Siirt ili arazi kullanım kabiliyet sınıfları

\begin{tabular}{lrr}
\hline Arazi Kullanım Kabiliyet & Alan (ha) & Oran (\%) \\
Sinıfları (AKK) & 6957.37 & 1.24 \\
\hline I & 16561.94 & 2.94 \\
II & 25566.18 & 4.54 \\
III & 31445.70 & 5.59 \\
IV & 152.00 & 0.03 \\
V & 64202.54 & 11.41 \\
VI & 380586.52 & 67.65 \\
VII & 35530.58 & 6.32 \\
VIII & 1515.18 & 0.27 \\
YR: Yerleşim & 101.49 & 0.02 \\
GL: Göl & 562619.50 & 100.00 \\
\hline Toplam & & \\
\hline
\end{tabular}




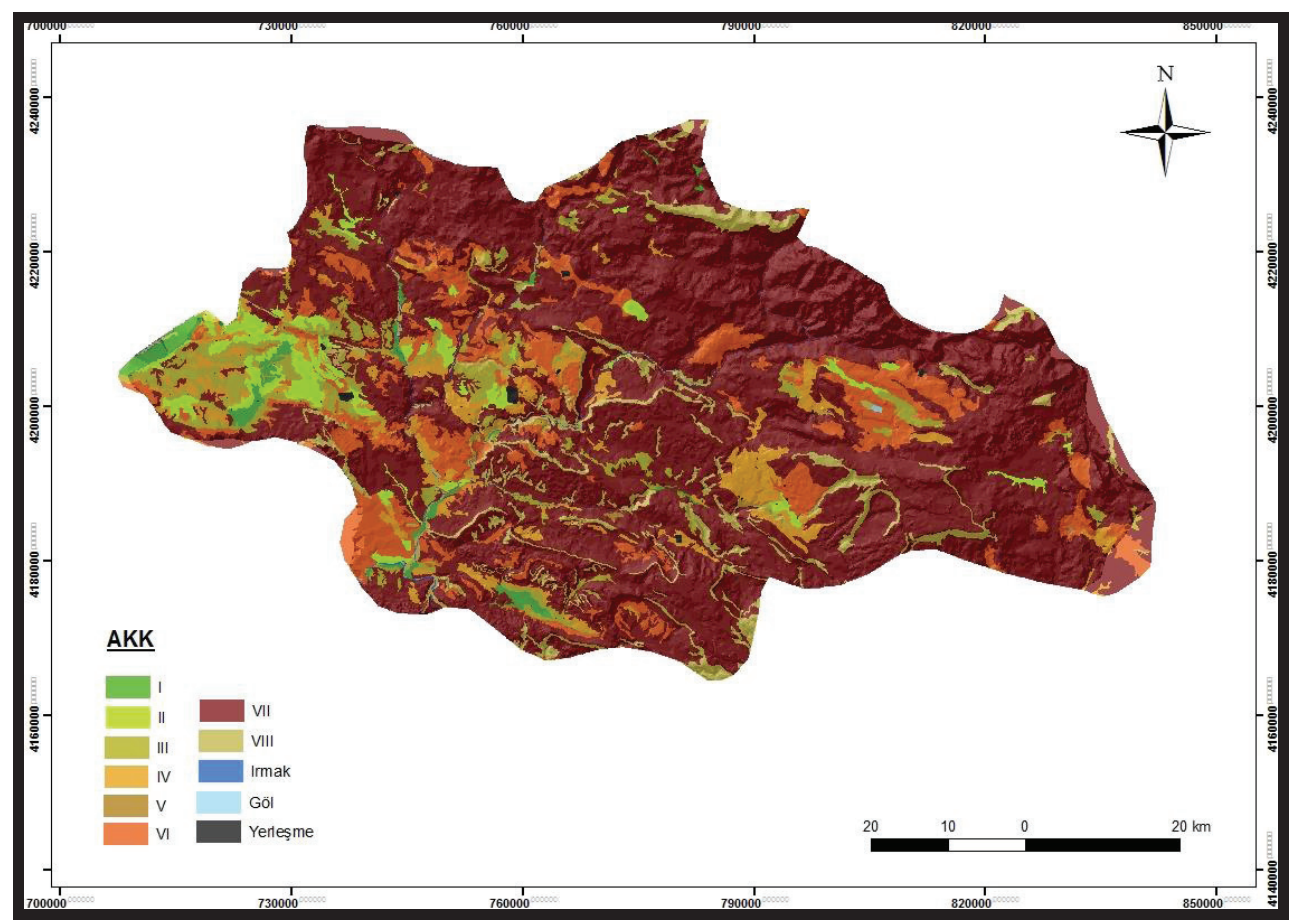

Şekil 8. Siirt ili arazi kullanım kabiliyet haritası

Topraklarin su ve besin maddelerinin tutulumunun yanı sıra iyi bir kök gelişimi açısından önemli bir özellik olan toprak derinliği yönünden incelendiğinde, çalışma alanının olduça az bir alanı derin ve orta derin alanlara sahiptir. Toprak derinlik haritası incelendiğinde, \% 67.27 oranıyla sahanın büyük kısmının çok sığ topraklardan oluştuğu görülmektedir. Ayrıca \% 17.26'sının da sı̆ topraklarla kaplı olduğu görülmektedir (Tablo 6). Derin ve çok derin toprakların ise batıda ovalık arazilerde ve vadilerde yer aldığ 1 , fakat bu derinlik sinıflarındaki toplam alanın çok düşük olduğu görülmektedir (Şekil 9).

Tablo 6. Siirt ili toprak derinlik sınıfları

\begin{tabular}{|c|c|c|}
\hline Toprak Derinliği (cm) & Alan (ha) & Oran $(\%)$ \\
\hline : 0-20- Cok siğ & 378453.24 & 67.27 \\
\hline$: 20-50-\mathrm{S} 1 \mathrm{~g}$ & 97084.40 & 17.26 \\
\hline : 50-90-Orta Derin & 31960.27 & 5.68 \\
\hline d4 : $90+$ Derin & 16661.80 & 2.96 \\
\hline CK : Çıplak Kayalık & 33257.16 & 5.91 \\
\hline YR : Yerleşim & 1509.52 & 0.27 \\
\hline IY : Irmak Yatağ & 2140.49 & 0.38 \\
\hline IR : Irmak & 1330.95 & 0.24 \\
\hline GL : Göl & 101.49 & 0.02 \\
\hline SB : Sazlık Bataklık & 120.18 & 0.02 \\
\hline Toplam & 562619.50 & 100.00 \\
\hline
\end{tabular}

\subsection{Siirt ili toprak verimlilik özellikleri}

Ülkemiz topraklarının özellikleri ve verimlilik durumlarının belirlenmesi amacıyla yapılan en kapsamlı çalıșma, (Mülga) Köy Hizmetleri Genel Müdürlüğü tarafından 1980-1991 yılları arasında yürütülen "Türkiye Topraklarının Verimlilik Envanteri Projesi (TOVEP)"dir. Bu proje kapsamında il düzeyinde toprakların temel bitki besin maddeleri olan azot, fosfor ve potasyum durumları ile toprakların organik madde, $\mathrm{pH}$, kireç durumları ve bünye sınıfları incelenmiş olup, sonuçlar 1/100000 ölçekli haritalarla "İl Verimlilik Envanteri ve Gübre İhtiyaç Raporları" adı altında yayınlanmıştır. Siirt ili topraklarının temel verimlilik özelliklerine ait eldeki tek verileri bu raporlar (Anonim, 1984) teşkil etmektedir. Buna göre; Siirt ili tarım yapılan toprakların üst katının (0-20 cm) suyla doygunluk cinsinden bünyesi, \% 6.6's1 kumlu, \% 16.1'i tınlı, \% 70.1'i killi-tınlı, \% 7.1'i killi ve \% 0.1 'i ağır killidir. Toprakların \% 24.0'1 nötr ve \% 76.0'1 hafif alkali reaksiyonlu olup, toprakların \% 98.5'inde tuzluluk problemi bulunmamaktadır. Siirt ili tarım topraklarının \% 6.8'i az kireçli, \% 62.9'u kireçli, \% 30.0'1 orta kireçli ve \% 0.3 'ü çok fazla kireçli olup, toprakların \% 6.8'i çok az, \% 47.9'u az, \% 34.3'ü orta, \% 8.7'si iyi ve \% 2.3'ü yüksek düzeyde organik madde içermektedir. İncelenen 1099 toprak örneğinin \% 50.9'unda alınabilir fosforun $\left(\mathrm{P}_{2} \mathrm{O}_{5}\right)$ çok az, \% 33.5'inde az, \% 6.2'sinde orta, \% 4.4'ünde yüksek ve \% 5.0'ında ise çok yüksek; tarım yapılan toprakların tamamında alınabilir potasyumun $\left(\mathrm{K}_{2} \mathrm{O}\right)$ ise fazla seviyede olduğu belirlenmiştir (Anonim, 1984). Bu veriler Siirt ilinde yapılan gübre üretimi ve tüketimi ile gübreleme ve sulama çalışmalarında, özellikle planlama safhalarında ciddi bir şekilde yararlanılan ve her zaman başvurulan temel bir kaynak 
özelliğinde olmuştur. Ancak o zamanki imkânlarla yapılan bu çalışmalarda, başta toprak örneklerinin koordinatlarının belirlenmemiş olmasının yanında, söz konusu örneklerin pek çoğunda mikro bitki besin maddeleri ve çeşitli yollarla tarım alanlarına bulaştırılarak, toprak kirliliğine sebep olan ağır metal analizlerinin yapılmamış olması, bu çalışmadan elde edilen sonuçları günümüzde yetersiz k1lmaktadır.

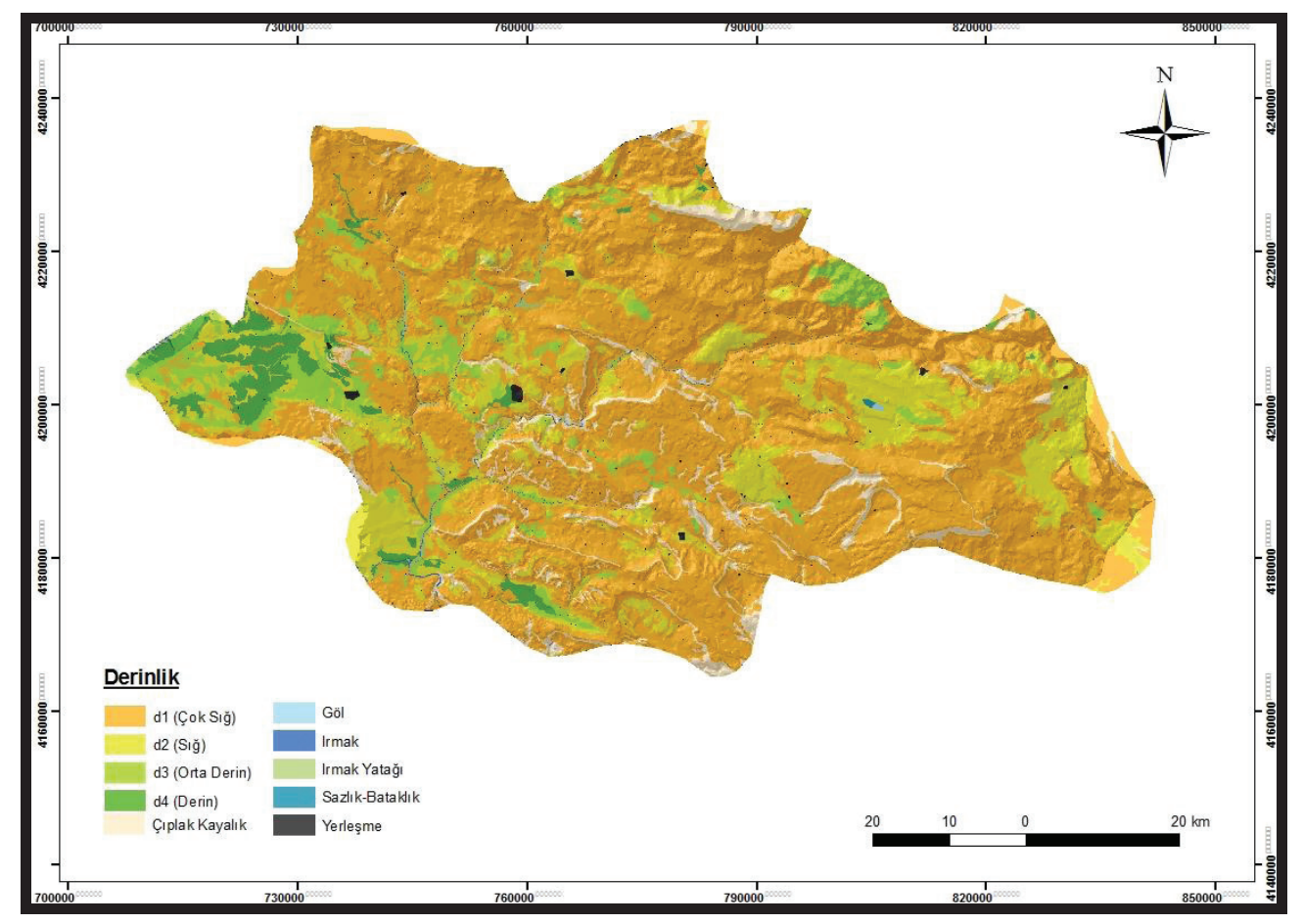

Şekil 9. Siirt ili toprak derinlik haritası

\section{Sonuçlar}

Toprak verilerinin topoğrafya bilgileriyle birlikte analizi büyük bir önem taşımaktadır. Bir alanın topoğrafyasını incelemek, üçüncü boyut olan yükseklik bilgisini analizlere katarak iki boyutlu analizlerle mümkün olmayan daha kapsamlı analizlerin yapılmasını sağlamaktadır. Bunun nedeni, bazı arazilerin tarıma elverișli olmalarına rağmen topoğrafya açısından elverişli olmamasıdır (Dengiz ve Sarığlu, 2011a). Yüksek eğimi olan arazilerin tarım amaçlı kullanılması, toprak kaybına ve erozyona neden olacağı için sakıncalıdır. Bu durumun analizi, hangi arazinin; hem arazi kullanım kabiliyeti, hem de arazinin yüksekliği açısından tarıma elverişli olduğunu ortaya çıkaracaktır. Bu bakımdan, bu çalışmada Siirt ilinin sayısal yükseklik modelinin yaratılması ve temel bazı coğrafi haritaların üretilmesi gereği ortaya çıkmıştır.

Siirt ili topraklarının topoğrafik koşulları nedeniyle gerek işlemeli tarıma uygun çok az alanların olduğu, gerekse de toprak erozyonunun potansiyel tehdidi altında olduğu ve düz eğimli araziler dışında kalan il arazi varlığının çok büyük bir kısmının özel önlemlere ihtiyaç duyduğu belirlenmiştir. Dolayısıyla arazi ve toprak kaynaklarına ait özelliklerinin belirlenmesi ve haritalanma çalışmaları; bu alanlarda uygulanacak olan tarımsal faaliyetler, arazi veya havza planlama çalışmaları gibi önemli konularda daha detaylı ve işlevsel planlar yapılabilmesi için zorunluluktur. $\mathrm{Bu}$ sebeple arazi ve toprak kaynaklarımızın incelenmesinde bu çalışmada olduğu gibi rakamsal ve görsel verilerle ortaya konulması önemli yararlar sağlayacaktır.

\section{Kaynaklar}

Akgül, M., Başayiğit, L., 2005. Süleyman Demirel Üniversitesi çiftlik arazisinin detaylı toprak etüdü ve haritalanmas1. Süleyman Demirel Üniversitesi Fen Bilimleri Enstitüsü Dergisi, 9(3): 1-10.

Anonim, 1984. Siirt İli Verimlilik Envanteri ve Gübre İhtiyaç Raporu. T.C. Tarım Orman ve Köyişleri Bakanlığ1 Topraksu Genel Müdürlüğü Yayınları, Genel Yayın No: 770, TOVEP Yayın No: 31, Ankara. 
Anonim, 1997. Siirt İli Arazi Varlığı. T.C. Başbakanlık Köy Hizmetleri Genel Müdürlüğü Yayınları, Ankara.

Anonim, 2005. Siirt Tarım Master Planı. Tarım ve Köyişleri Bakanlığı, Siirt İl Müdürlüğü, Siirt.

Anonim, 2014. İllerimize Ait İstatistiki Veriler. T.C. Orman ve Su İşleri Bakanlığı Meteoroloji Genel Müdürlüğü.

http://www.mgm.gov.tr/veridegerlendirme/il-veilceler-istatistik.aspx?m= SIIRT\#sfB (Erişim tarihi: 25.03.2014).

Canpolat, O., 1981. Türkiye topraklarının tarımsal kullanıma uygunluk bakımından incelenmesi. DSI, Toprak ve Su Kaynaklarının Geliştirilmesi Konferansi Bildirileri, 1: 60-87.

Dengiz, O., Sağlam, M., Özaytekin, H.H., Baskan, O., 2013. Weathering rates and some physico-chemical characteristics of soils developed on a calcic toposequences. Carpathian Journal of Earth and Environmental Sciences, 8(2): 13-24.

Dengiz, O., Sarığlu, F.E., 2011a. Samsun ili bazı arazi özellikleri ve arazi kullanım durumlarının topoğrafik özellikleri ile birlikte CBS analizleri. Ege Üniversitesi Ziraat Fakültesi Dergisi, 48(1): 55-60.

Dengiz, O., Sarığlu, F.E., 2011b. Samsun ilinin potansiyel tarım alanlarının genel dağılımları ve toprak etüd ve haritalama çalışmalarının önemi. Anadolu Tartm Bilimleri Dergisi, 26(3): 241-253.

Harmon, J.E., Anderson, S.J., 2003. The design and implementation of geographic information systems. John Wiley \& Sons. Inc.. Hoboken, New Jersey, Published. 